\title{
RUSSIA'S FOREIGN TRADE IN AUGUST 2013
}

\author{
N.Volovik, K.Kharina
}

From April 2012, the Russian foreign trade has been in stagnation. In the past few months, growth rates of both export and import fluctuated near the zero level. Russia turned down the EU's request to the WTO to convene a panel of arbitrators to consider the issue of the existing mechanism of the utilization duty in Russia as there is still a chance to reach an amicable settlement.

In August 2013, the Russian foreign trade turnover calculated on the basis of the methods of the balance of payments amounted to $\$ 70.5 \mathrm{bn}$ which is $0.9 \%$ lower than the respective index of 2012. In August 2013, export amounted to $\$ 42.2 \mathrm{bn}$ having increased by $2.3 \%$ as compared to last August. The import fell by $5.3 \%$ to $\$ 28.4 \mathrm{bn}$. As a result, the surplus of the trade balance increased: in August 2013 it amounted to \$13.8bn which is 22.5\% higher than in August 2012.

The global oil market is still under the effect of the following two main factors: low growth rates of the global economy and geopolitical risks. As due to a concern over possible full-scale hostilities by Western countries in Syria, on August 27, 2013 the Brent oil price rose on a single day by $3 \%$ to the maximum value of $\$ 114.36$ a barrel from February 2013. In August, the average Brent oil price was formed in the amount of $\$ 110.96$ a barrel which is 3\% higher and 2.1\% lower than in July 2013 and the index of August 2012, respectively.

In August 2013, the average Urals oil price amounted to $\$ 111.11$ a barrel which is $1.8 \%$ lower as compared to the price in August 2012. In January-August 2013 the price decreased by $3.3 \%$ to $\$ 107.34$ a barrel as compared to the same period of 2012.

In January-September 2013, the average price of the Russian Urals oil amounted to $\$ 107.73$ a barrel which is $3.0 \%$ lower as compared to the same period of 2012.

According to the oil price monitoring carried out by the Russian Ministry of Finance, from September 15 till October 14, 2013 the average Urals oil price amounted to $\$ 108.7$ a barrel (\$793.8 a ton). As a result, from November 1, 2013 the export duty on crude oil will decrease by $4.9 \%$ to $\$ 395.9$ a ton from $\$ 416.4$ a ton in October. From November 1, 2013, the single rate of export duty on light and dark oil products, except for petrol, will amount to $\$ 261.2$ a ton against $\$ 274.8$ a ton in October. It is to be noted that in November the duty on petrol will be cut to $\$ 356.3$ a ton $(\$ 374.7$ a ton in October 2012).

The decision of the US Federal Reserve to preserve at the previous level the programs of repurchasing of

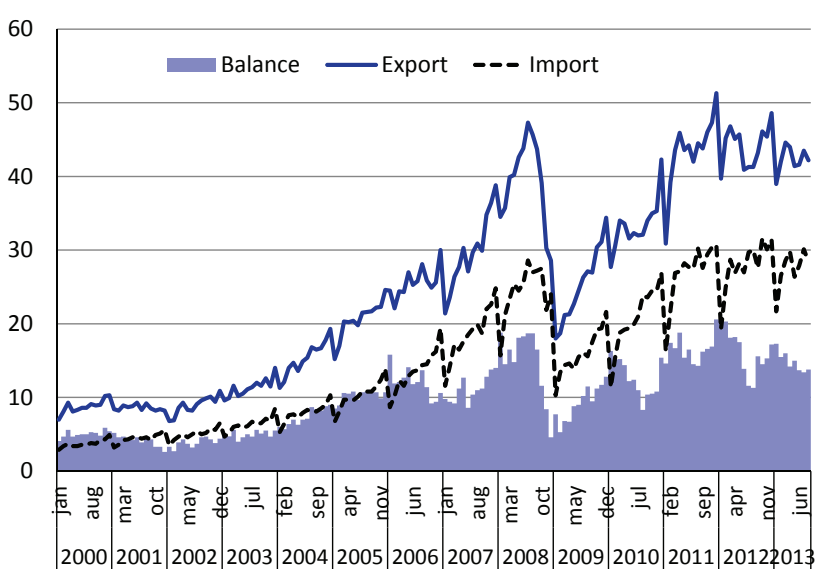

Source: Central Bank of the Russian Federation.

Fig. 1. The main indices of the Russian foreign trade (billion USD)

US government bonds stopped a drop in prices on nonferrous metals; the above drop continued from February 2013. In August 2013, as compared to the previous month prices on all the nonferrous metals increased: aluminum appreciated by $2.7 \%$, while copper and nickel, by $4.1 \%$ each. It is to be noted that as compared to August 2012, aluminum, copper and nickel cost $1.5 \%$, $4.3 \%$ and $9 \%$ lower, respectively.

For four months running, the FAO food price index has kept falling: in August 2013 its average value amounted to 201.8 points which is 4 points and 11 points lower than in July 2012 and August 2012, respectively. A decrease registered in August is related to a continued drop in global prices on grain and oil, while prices on dairy products, meat and sugar increased somewhat.

In January-August 2013, the foreign trade turnover of the Russian Federation amounted to $\$ 558.6 \mathrm{bn}$ which is $0.3 \%$ lower than the respective index of 2012 . It is to be noted that the Russian export decreased by $2.1 \%$ to amount to $\$ 338.2$, while the import rose by $2.6 \%$ to $\$ 220.4 \mathrm{bn}$. In January-August 2013 , the trade balance surplus of the Russian Federation amounted to $\$ 117.9$ bn which is $9.9 \%$ lower than in January-August 2012. 
MONTHLY AVERAGE GLOBAL PRICES IN AUGUST OF THE RESPECTIVE YEAR

\begin{tabular}{|l|c|c|c|c|c|c|c|c|c|c|c|c|}
\hline & 2002 & 2003 & 2004 & 2005 & 2006 & 2007 & 2008 & 2009 & 2010 & 2011 & 2012 & 2013 \\
\hline $\begin{array}{l}\text { Oil (Brent), } \\
\text { USD/a barrel }\end{array}$ & 27.2 & 29.9 & 42.8 & 61.9 & 71.7 & 72.1 & 118.3 & 73.06 & 77.18 & 109.9 & 113.3 & 110.96 \\
\hline $\begin{array}{l}\text { Natural gas*, } \\
\text { USD/1 m BTU }\end{array}$ & 3.01 & 3.98 & 4.34 & 6.56 & 8.71 & 8.34 & 14.64 & 6.92 & 8.45 & 10.81 & 11.18 \\
\hline $\begin{array}{l}\text { Copper, } \\
\text { USD/a ton }\end{array}$ & 1480.0 & 1731.0 & 2835.8 & 3800.0 & 7689 & 7510.5 & 7645.6 & 6165.3 & 7284 & 9001.0 & 7515.5 & 7192.9 \\
\hline $\begin{array}{l}\text { Aluminum, } \\
\text { USD/a ton }\end{array}$ & 1292.0 & 1457.0 & 1694.3 & 1868.0 & 2460 & 2515.2 & 2780 & 1933.8 & 2118.4 & 2379.0 & 1845.4 & 1817.6 \\
\hline $\begin{array}{l}\text { Nickel, } \\
\text { USD/a ton }\end{array}$ & 6720.0 & 9365.0 & 13723 & 14894 & 30872 & 27600 & 18581 & 19642 & 21413 & 21845 & 15735 & 14315 \\
\hline
\end{tabular}

* The Markets of Europe, the average contract price, Franco-border.

Source: calculated on the basis of the data of the London Metal Exchange (London, the UK) and the Intercontinental Oil Exchange (London).

A decrease in the export took place due to a considerable drop in export supplies of metals and metal articles, as well as food products and agricultural primary products. In January-August 2013, the cost of the volume of export of those groups of commodities fell by $12 \%$ and $11.3 \%$, respectively as compared the same period of 2012. It is to be noted that a drop took place both in physical volumes of exported goods and their export prices.

Despite the fact that the export of oil fell by $5.6 \%$ due to growth in the export of oil products $(9.8 \%)$ and gas $(6.8 \%)$, the export of fuel and energy commodities remained at the level of the previous year.

Export supplies of wood and pulp and paper products, machines, equipment and transportation vehicles and chemical products rose insignificantly by $2.4 \%, 1.9 \%$ and $0.1 \%$, respectively.

Growth in the import took place due to higher purchases of textile, textile products and footgear (7.6\%), food products and agricultural primary products $(5.1 \%)$, chemical products $(5 \%)$ and metals and metal articles (5\%). The import of machines, equipment and transportation vehicles decreased by $1.6 \%$. It is to be noted that the share of that group of commodities in the total volume of the Russian export decreased from 50.3\% in January-August 2012 to $48.7 \%$ in JanuaryAugust 2013.

On October 9, 2013, the eighth meeting of the Council of the Eurasian Economic Commission took place. At the above meeting, decisions were passed as regards technical regulation, competition and antitrust policy, customs and tariff regulation and trade in member-states of the Customs Union.

Technical regulations of the Customs Union on Safety of Milk and Dairy Products and On Safety of Meat and Meat Products were approved.

Due to accession of the Russian Federation to the WTO, the process of reduction of the rates of the sin- gle customs duty of the Customs Union keeps going on. So, by Decision No.58 of October 9, 2013 of the Council of the Eurasian Economic Commission the rate of the import duty on Prunus plum puree and spreads in a primary package with net weight of over $100 \mathrm{gr}$. for industrial processing were reduced to $13 \%$ against the present $13.7 \%$ of the customs value.

Also, the rate of the import duty on ethylene copolymers with vinyl acetate was reduced from $8.8 \%$ to $6.5 \%$ as well as that on paving slabs and finish tiles (from $13 \%$ to $12 \%$ ). In addition to the above, the rate of the import duty on electronic players (deca) and other sound-reproducing equipment without a soundrecording device is reduced from $12.3 \%$ to $11 \%$. The decision becomes effective from December 31, 2013.

In October 2013, the period of 60 days established in accordance with the WTO rules in order to achieve an amicable agreement with the EU as regards the latter's claim in respect of the utilization duty introduced in Russia expired. It is to be reminded that while the duty is imposed on the entire import from the EU, motor vehicles produced in Russia, Kazakhstan and Belarus are exempted from it. So, the utilization duty creates advantages for car makers from the Customs Union, which situation contradicts the WTO norms.

According to the data of the Federal Treasury of the Russian Federation, from the day the utilization duty was introduced in September 2012 the federal budget revenues from that tax amounted to $\mathrm{Rb} 55.4 \mathrm{bn}$.

The bilateral consultations carried out on July 2930, 2013 failed to eliminate differences. On October 10, 2013 the EU turned to the authority which resolves the WTO disputes with a proposal to convene a panel of arbitrators which will consider the issue of legitimacy of such a duty.

On October 22, 2013, the WTO Committee on Resolution of Disputes was held in Geneva where the Russian representative opposed the EU's request to the 
WTO to convene a panel of arbitrators to consider the issue of the existing utilization duty mechanism in Russia as a possibility of an amicable settlement of the dispute was not yet exhausted. If the EU raises the issue again at the next meeting, Russia has not right to block it for the second time.

In such a case, before the end of the year the WTO group of arbitration is to be formed and it will have within six months to determine if the EU's claims are justified or Russia's actions are in conflict with the WTO rules. After that, Russia will be granted 30 days to inform how it is going to fulfill the decision of the arbitration group. If the claims are found justified and Russia does not abolish discriminatory measures, the EU will be granted the right to introduce countervailing measures in respect of Russian goods. The EU will manage to increase duties to make up for the damage caused by European manufacturers. The sum of the damage is to be calculated by the arbitration group.

In combination with other factors, the utilization duty would have an effect on the volumes of import duties in Russia. So, in January-August 2013 the import of trucks into Russia in physical terms was 33.5\% lower than in January-August 2012. The import of light vehicles dropped dramatically as well: during the eight months of 2013 their import was 21.6\% lower than during the eight months of 2012. However, it is difficult to evaluate a decrease in supplies of cars from the EU due to the effect of the utilization duty as the Russian auto market shrinks under the effect of many factors.
The claim filed by the EU's authorities to the WTO court in July 2013 made the Russian authorities to reconsider its position. On October 21, 2013, Vladimir Putin, President of the Russian Federation signed such amendments to the Law on Production and Consumer Waste as make conditions of an utilization payment equal both to Russian and foreign car makers. Under the new law which becomes effective from January 1, 2014, the utilization duty will be charged not only from transport vehicles imported from abroad, but also from those manufactured in the territory of the Customs Union. An exception is made only in respect of vehicles owned by compatriots who move to live in Russia on a permanent basis in accordance with a special program and diplomatic and consular missions. In addition to the above, rare vintage cars manufactured at least 30 years ago are exempted from that duty.

Despite the fact that Russia has fulfilled the requirements of the European Union as regards making conditions of payment of the utilization duty equal both to importers and domestic manufacturers, Brussels still expects "further information and explanations". The EU has claims as regards the methods of calculation of the utilization duty. In particular, the EU believes that the duty should not depend on the engine volume of a car and that the method of calculation allows for a big difference between the amount of the duty on new cars and that on used ones. 